\title{
Lithosphere Structure and Mantle Terranes: Slave Craton, Canada
}

\author{
Griffin, W.L. ${ }^{1,2}$, Doyle, B.J. ${ }^{3}$, Ryan, C.G. ${ }^{2,1}$, Pearson, N.J. ${ }^{1}$, O’Reilly, S.Y. ${ }^{1}$, \\ Natapov,L. ${ }^{1}$, Kivi, K. ${ }^{4}$, Kretschmar, U. ${ }^{5}$ and Ward, J. ${ }^{6}$
}

1. GEMOC National Key Centre, School of Earth Sciences, Macquarie University, NSW 2109, Australia

2. CSIRO Exploration and Mining, P.O. Box 126, North Ryde, NSW 2113, Australia

3. Kennecott Canada Exploration Inc., 200 Granville St., Vancouver, B.C. V6C 1S4, Canada

4. Kennecott Canada Exploration Inc., 1300 Walsh St., Thunder Bay, Ontario P7E 4X4, Canada

5. Kretschmar Geoscience, 408 Bay St., Orillia, Ontario L3V 3X4, Canada

6. Ashton Mining of Canada Inc., Unit 123-930, West 1st St., North Vancouver, B.C. V7P 3N4, Canada

Xenoliths and heavy mineral concentrates $(>1500$ garnets and chromites from 21 kimberlite intrusions) were used to map the composition, structure and thermal state of the lithospheric mantle beneath the Lac de Gras area. P-T estimates for xenoliths from the A154 pipe, combined with those of Boyd and Canil (1997) for the Grizzly pipe, define a geotherm that is close to or below a 35 $\mathrm{mW} / \mathrm{m}^{2}$ conductive model geotherm for temperatures $<900^{\circ} \mathrm{C}$, and close to a $38 \mathrm{~mW} / \mathrm{m}^{2}$ model at $\mathrm{T}$ $\geq 900{ }^{\circ} \mathrm{C}$ (Pearson et al., this volume). P-T estimates based on garnet and chromite concentrates (Ryan et al., 1996) define a similar stepped geotherm (Fig. 1), which may separate two layers with different conductivity. High-T sheared xenoliths are present, but do not define a "kink" in the geotherm.

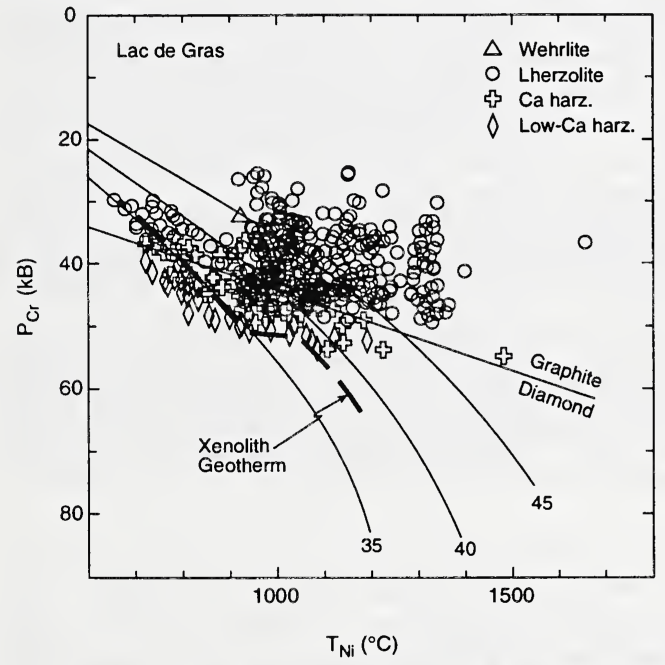

Fig. 1. P-T plot for garnet xenocrysts

A boundary between two layers of the lithospheric mantle is well defined by plots of trace- and major-element data vs Nickel Temperature $\left(\mathrm{T}_{\mathrm{Ni}}\right)$ for concentrate garnets (Fig. 2). Projection of the temperature of this boundary to the geotherm derived from xenoliths and concentrates places it at a depth of $150 \pm 10 \mathrm{~km}$ beneath the Lac de Gras area. Both harzburgitic and lherzolitic garnets from the shallower layer have extremely low levels of $\mathrm{Y}, \mathrm{Zr}$, Ti and $\mathrm{Ga}$. The median contents of these elements ( $\mathrm{Ti}, 380 \mathrm{ppm}$; Y, $1.5 \mathrm{ppm} ; \mathrm{Ga}$, $4 \mathrm{ppm}, \mathrm{Zr}, 5 \mathrm{ppm}$ ) are lower than $90 \%$ of the values found in garnets from Archean cratons worldwide (Griffin et al., 1998), indicating that this layer is ultradepleted. The garnets of the deeper layer are more typical of Archean garnets worldwide (median Ti, 1800 ppm; Y, 8 ppm; Ga, 8 ppm, Zr, 33 ppm), and depleted compositions like those of the shallower ultradepleted layer are rare in the deeper layer.

A small population of garnets with $\mathrm{Ti}-\mathrm{Zr}-\mathrm{Y}$ rich signatures characteristic of high- $\mathrm{T}$ sheared xenoliths suggests that the base of the (chemically defined) lithosphere has $\mathrm{T}_{\mathrm{Ni}}=1200-1250{ }^{\circ} \mathrm{C}$, corresponding to 200-220 km beneath the central part of the Lac de Gras area.

Garnet and chromite data and available xenoliths indicate that the shallower layer consists of approximately $60 \%$ harzburgite and $40 \%$ lherzolite, both with similar olivine compositions (mean Fo=92.7). At depths shallower than $100 \mathrm{~km}$, garnet disappears and the Al-Cr phase is spinel. The deeper layer of the lithospheric mantle contains $<17 \%$ harzburgite, and most of this is concentrated in the upper part of this layer (Fig. 2); mean olivine composition is Fo=91.5. T estimates on xenoliths indicate that all eclogites are derived from the deeper layer, but are bimodally distributed with $\mathrm{Al}$-rich compositions near the bottom of the layer, and Al-poor compositions near the top (Pearson et al., this vol.).

The two-layered lithospheric structure has been mapped in detail over an area ca $60 \times 30 \mathrm{~km}$ around Lac de Gras, and is consistent from pipe to pipe. The wider lateral extent of this structure (Fig. 3) has been mapped using concentrates from outlying pipes, including the Ranch Lake pipe to 

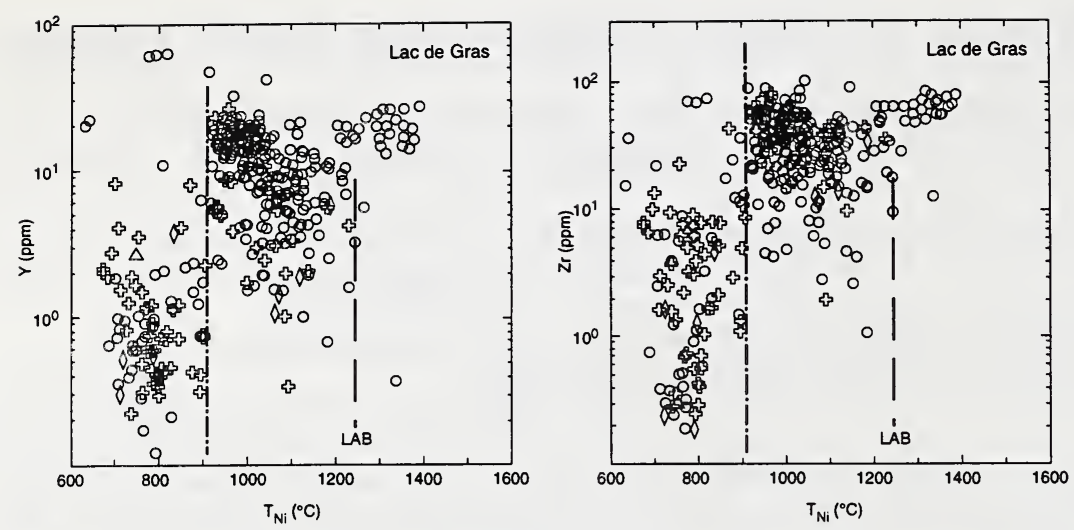

Fig. 2. $\mathrm{Y}$ and $\mathrm{Zr}$ vs $\mathrm{T}_{\mathrm{Ni}}$ for garnets, showing the two lithosphere layers, and the LAB boundary. Symbols as in Fig. 1 the north, the Cross Lake cluster to the SW, the Drybones pipe near Yellowknife, and isolated exploration samples. Limited data from pipes A44 and PL01 indicate that the two-layer structure extends at least 50 $\mathrm{km} \mathrm{E}$ and $\mathrm{NE}$ from Lac de Gras. This structure also is well-defined beneath the Ranch Lake pipe, ca 80

$\mathrm{km} \mathrm{NW}$ of Lac de Gras, where the boundary is at ca $140 \mathrm{~km}$ depth. However, at Ranch Lake the base of the (chemically defined) lithosphere has shallowed to ca $170 \mathrm{~km}$, and the proportion of harzburgite in both the shallower and deeper layer has decreased.

Concentrate garnets from the Camsell Lake area, $100 \mathrm{~km} \mathrm{~S}$ of Lac de Gras (Pokhilenko et al., 1997) do not include the population of low-Ca, moderate-Cr harzburgitic garnets that characterises the shallow layer beneath Lac de Gras. The range of FeO contents in the Camsell Lake garnets also requires relatively fertile lherzolitic material at shallow depth, and the proportion of G10 garnets in the concentrate is $15-17 \%$, as in the deeper layer beneath Lac de Gras. The distribution of $\mathrm{CaO}$ contents in low-Cr garnets also is bimodal at Camsell Lake, as in the deeper layer at Lac de Gras. These data suggest that the shallow ultradepleted layer is absent, or is $<100 \mathrm{~km}$ thick, in the southern part of the craton, and that most of the lithospheric mantle consists of material similar to the deeper layer beneath Lac de Gras.

Ultramafic xenoliths from the Jericho pipe, ca. $80 \mathrm{~km} \mathrm{~N}$ of Ranch Lake, are lherzolitic, with relatively low-Cr garnets (Kopylova et al.,this vol.). The $\mathrm{T}_{\mathrm{Ni}}$ distribution of $\mathrm{Cr}, \mathrm{Zr}$ and $\mathrm{Y}$ contents of garnet shows that the shallow ultra- depleted layer is absent, and the stratigraphy and garnet composition are characteristic of Proterozoic, rather than Archean, mantle (Griffin et al., 1998). This suggests a major boundary in the lithospheric mantle, which may correspond to the position of the Proterozoic Kilohigok Basin.

Concentrate garnets from the pipes of the Cross Lake cluster define a $38 \mathrm{~mW} / \mathrm{m}^{2}$ geotherm similar to that in the deeper layer of the Lac de Gras section, but without any step; the base of the lithosphere lies at ca $180 \mathrm{~km}$. The ultradepleted upper layer is absent, or <100 km thick; the depth range $100-140 \mathrm{~km}$ is occupied almost entirely by moderately depleted lherzolites. The analysed section contains ca 16\% harzburgite (as defined by "G10" garnets), concentrated in the depth range $140-160 \mathrm{~km}$, and the median garnet $\mathrm{Cr}, \mathrm{Zr}$ and $\mathrm{Y}$ contents are similar to those of the deeper layer beneath Lac de Gras. High-Ca eclogitic garnets are present, but the bimodal distribution seen in the Lac de Gras sections is not evident.

Peridotitic garnets from the Drybones pipe on the SW margin of the craton are derived entirely from $<140 \mathrm{~km}$ depth, and are are lherzolitic, with a median $\mathrm{Cr}_{2} \mathrm{O}_{3}$ content of ca $5 \%$. Many garnets from depths $<130 \mathrm{~km}$ are depleted in $\mathrm{Zr}$ and $\mathrm{Y}$, but the lack of harzburgitic garnets in this layer distinguishes it from the mantle at similar depths beneath Lac de Gras. This section is most typical of Proterozoic, rather than Archean, lithospheric mantle.

The shallow, ultradepleted layer of the lithospheric mantle has been mapped over an area of at least $18,000 \mathrm{~km}^{2}$ centred on Lac de Gras (Fig. 3). It appears to be absent, or $<100 \mathrm{~km}$ thick, beneath the SE part of the craton, and apparently does not cross the Sleepy Dragon Belt to the Cross Lake area. The deeper layer appears to extend further, rising to depths $\leq 120 \mathrm{~km}$ beneath the Camsell Lake and Cross Lake areas. The shallow layer is interpreted as lithosphere formed in a convergent-margin setting, analogous to modern depleted sub-arc mantle, during the $2.75-2.6 \mathrm{Ga}$ accretion of the eastern part of the Slave craton to the existing continental nucleus of the western 


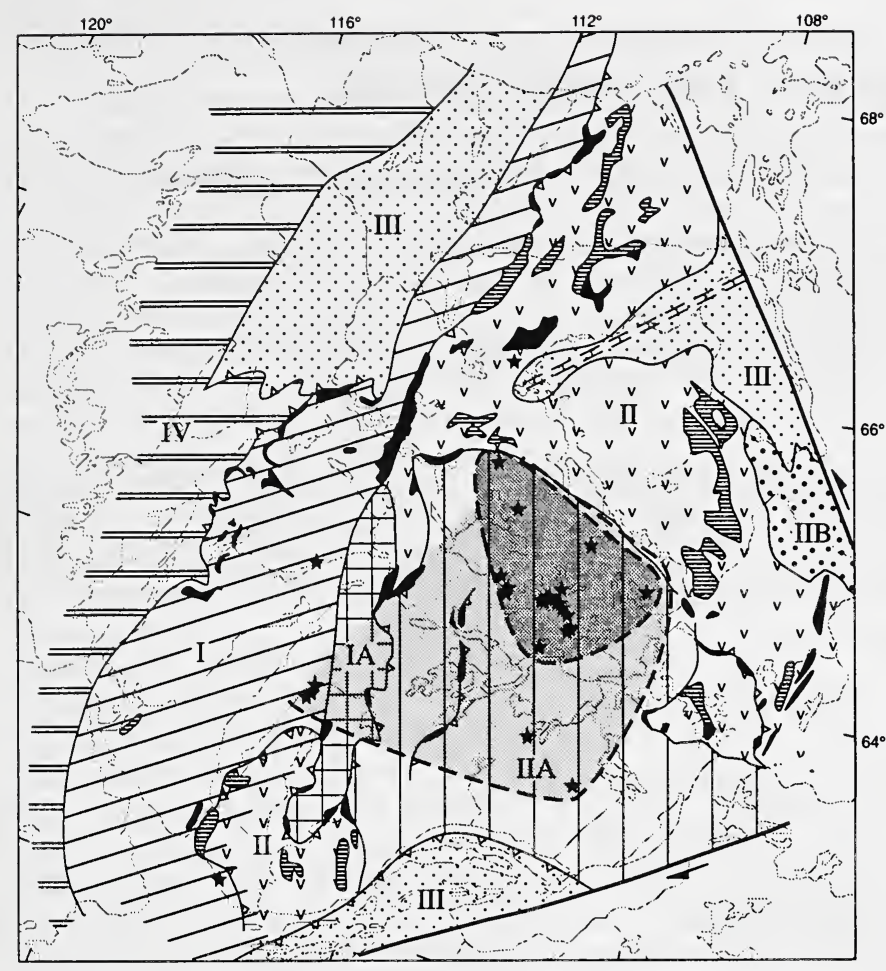

Fig. 3. Terrane map of Slave Craton, showing minimum extent of the shallow ultradepleted layer (dark shading) and of the deeper less depleted layer (light shading). I, Anton Terrane (ancient continental core); IA, Sleepy Dragon domain; II, Hackett River Terrane (island arcs); IIA, Contwoyto Terrane (accretionary prism); IIB, Beechy Lake domain; III, passive margins, Kilohigok Basin (Proterozoic cover); IV, Proterozoic mobile belt. part. The deeper layer of the lithospheric mantle contains many diamonds $(\approx 25 \%$ of the population) with the ultradeep ferropericlase- $\mathrm{Mg}$-perovskite assemblage (Davies et al., this volume), many eclogitic diamonds with very low $\partial^{13} \mathrm{C}$, and kyanite eclogite xenoliths with anorthositic-troctolitic compositions (Pearson et al., this volume), suggesting a component of recycled crustal material. This deeper layer is interpreted as the head of a plume or diapir, incorporating both moderately depleted mantle and subducted crustal material, that has risen from $>650 \mathrm{~km}$ depth to accrete onto the base of the craton. The pre-existing lithosphere was ca $150 \mathrm{~km}$ thick and ultradepleted beneath the centre of the craton (Fig. 3), but thinner and/or less refractory to the $S$ and SW. This mantle-underplating event may be related to the widespread post-orogenic $(2.5-2.6 \quad \mathrm{Ga})$ granitoid magmatism in the Slave Province, and heat from this event may have caused further depletion of the shallow layer where it was present.

The apparently Proterozoic lithospheric mantle beneath the Jericho pipe may represent older lithosphere reworked during the Mackenzie plume event $(1.27 \mathrm{Ga})$; similar mantle is reflected in garnet concentrates from kimberlites on Victoria Island, closer to the plume focus (this work). Alternatively, it may have been generated during rifting processes that led to the formation of the Proterozoic Kilohigok Basin. The mantle sampled by the Drybones pipe on the SW corner of the craton is not typically Archean; it may have been reworked or replaced during Proterozoic subduction from the west, or during transcurrent movement along the major MacDonald Fault.

\section{References}

Boyd, F.R. and Canil, D., 1997. Goldschmidt Conf. Abstracts, 34-35.

Griffin, W.L., Doyle, B.J., Ryan, C.G., Pearson, N.J., O’Reilly, S.Y, Davies, R., Kivi, K. and van Achterbergh, E., 1998. Jour. Petrol., subm.

Pokhilenko, N.P., McDonald, J.A., Melnik, U., McCorquodale, J., Reimers, L.F. and Sobolev, N.V., 1997. Russian Geology and Geophys., 38, 550-558.

Ryan, C.G., Griffin, W.L. and Pearson, N.J., 1996. Jour Geophys. Res., 101, 5611-5625. 